\title{
Military Background, Political Connection, Audit Quality and Earning Quality
}

\author{
Arif Widodo and Zaenal Fanani \\ Master of Accounting, Economic and Business Faculty, Airlangga University, Indonesia \\ Email: arif.wdd@gmail.com andfanani@feb.unair.ac.id
}

\begin{abstract}
This research is try to determine the effect of military background and political connections on earning quality with audit quality as a mediator. This research uses a quantitative approach using a sample of mining sector company that listing in Indonesia Stock Exchange in the 2017-2018 periods. The conclusion of this research points out that military background has positive effect on audit quality and political connections negatively affect earning quality. While earning quality not effected by the military background, political connections do not effect audit quality, and earnings quality not effected by audit quality. Likewise, for the hypothesis, mediation of the audit quality has no effect on the relationship of military background and political connections to earnings quality.
\end{abstract}

Keywords: military backgrounds, political connection, earning quality, audit quality.

Abstrak: Penelitian ini bertujuan untuk melihat efek latar belakang militer dan koneksi politik terhadap kualitas laba dengan kualitas audit sebagai pemediasi. Penelitian dilaksanakan dengan pendekatan kuantitatif mempergunakan sektor pertambangan yang go public pada periode 2017-2018 sebagai sampel. Hasilnya, ditemukan bahwa latar belakang militer memberi pengaruh positif pada kualitas audit dan koneksi politik memberi pengaruh negatif pada kualitas audit. Sedangkan latar belakang militer tidak berpengaruh pada kualitas laba, dan koneksi politik tidak berpengaruh terhadap kualitas audit. Serta kualitas audit tidak berpengaruh pada kualitas laba. Begitu juga untuk hipotesis mediasi kualitas audit tidak berpengaruh pada hubungan latar belakang militer dan koneksi politik terhadap kualitas laba.

Kata Kunci: latar belakang militer, koneksi politik, kualitas audit, kualitas laba.

\section{INTRODUCTION}

Board of Directors and Commissioners are obliged to manage the company with good corporate governance and prioritizing the interests of shareholders while remaining in compliance with applicable laws and regulations. One form of management responsibility in managing a company is reporting financial statements with performance criteria set by shareholders. The profit reflected in the financial statements is one of the keys to fulfil the expectations of shareholders. This condition will greatly affect management's decisions in preparing financial statements, especially if the company is experiencing a bad business condition. Management has a great opportunity to prepare financial statements which does not represent the company's real condition, in order to secure its interests, welfare and 
reputation. Company management with various backgrounds, political connections and experience before serving as company management, will be able to give a big influence in making decisions when preparing financial statements that will affect reported earnings quality.

On the other hand, auditors of the Public Accounting Firm have an important role to ensure the financial statements which presented by management are in compliance with the actual situation and applicable accounting standards. Public Accounting Firm is expected to have a good reputation and quality in meeting these qualities. In this research, we use size of the Public Accounting Firm whether its Big-4 or non-Big-4 as a representative measure of audit quality.

This research uses one of the measurements recommended by (Hu, 2015), the quality of audits measured through the size of the Public Accounting Firm that divided into Big four and non-Big four categories. Measurement of earnings quality also take from one of the measurements recommended in the research, namely accruals. In some previous studies explained that accruals are one of the determinants of earnings quality that represent earnings management (Campa, 2013).

Some of these issues led us to conduct this research, namely examining whether military background and political connections influence audit quality and earning quality, and whether audit quality mediates the influence of military background and political connections towards earnings quality.

The population used in this research are mining companies which listed on the Indonesia Stock Exchange and the sample is taken from the period between 2017-2018. According to the results of the tests, using 50 samples using the PLS (Partial Least Square) model, it was concluded that the military background has a positive effect towards audit quality, this indicates that companies that have management with a military background have better audit quality (in this case has a tendency to appoint Big-4 Public Accounting Firm) and political connections negatively affect earnings quality.

This research provides new evidence to the existing literature regarding the relationship of military background which can significantly affect audit quality because management have influences the decision of Public Accounting Firm to be appointed in auditing the company's financial statements and political connections have a negative influence on earnings quality.

This journal is presented in five parts. While the first part is introducing about the whole topics and research, the second part is presenting theoretical review and developing the research's hypotheses, the third part explaining the data and measurement methods used in this research, the fourth part explaining the research model calculations and lastly the fifth part summarizing and concludes this research.

\section{THEORETICAL REVIEW}

Agency Theory. Agency theory is a part of positive theory that explains the relationship between parties who have resources (principals/ shareholders) and management (agents) to manage these resources (Adams, 1994). One of commonly discussed matter in this theory is that either the principal or the agents have its own objective to maximizes their own prosperity which leads to the agents act not in accordance to the order from the principals. This situation is appeared mainly because of the difference of information, or known as 
information asymmetry, so that the principal cannot supervise whether the appointed agent do the job as what the principal's ordered.

The Management, Board of Commissioners (BOC) and Board of Directors (BOD), is chosen by the principal based on whether the candidates has a good reputation in managing the company. Reputable management appointed by the principal has a variety of different backgrounds, one of which has a background of experience in the military and its relation to the political world (political connections).

Management is obliged to run the company with good corporate governance and manage the company efficiently, prioritizing the interests of the principal. One form of management responsibility in managing a company is shown through financial reports and other performance reports that are determined by regulations and / or principal interests. Principal requires qualified independent auditors to audit the company to guarantee the accuracy of the financial statements.

Quality audits conducted by independent auditors will increase the principal's belief that management presents financial reports and / or other performance reports appropriately. The fairness of the company's profit presentation as one of the auditors output is a very important measure for company performance and improvement in principal welfare. Principal has high expectations that a quality audit will produce quality profits.

Political Connections. There are several studies prove that political connections affect company's performance. Previous research explains that political connections have several benefits for companies, such as the ability to get sources of financing and get contracts with the government. Other research also shows that company's financial statements quality is affected by political connections (Harymawan and Nowland, 2016). Other research conducted by (Fan et al., 2007) shows that companies managed by CEOs who have political connections achieved lower performance compared to other companies. Furthermore, political connections in companies can generally be seen from the political relations held by Commissioners and Directors who hold concurrent positions as politicians affiliated with political parties or government officials and or former government officials.

Military Background. On the other hand, the military background of management also has an influence on company performance. Military background is the experience possessed by Directors and or Commissioners in the military world. The CEO of a company with a military background is proven to have success. The values gained when entering the military provide a lot of experience that is very useful in carrying out his job as CEO of the company. The values of discipline, obedience, ability to withstand high pressure are some of the advantages possessed by someone who has a military background. Research on military background is still limited, one of them is (Benmelech and Frydman, 2015) study which concluded that CEOs with a military background have a tendency to be cautious in making decisions and reduce the possibility of companies being exposed to fraud. In dealing with crisis or difficulties in business, companies which managed by CEOs with military backgrounds have better chance to survive and thrive. Management with a military background also has a tendency to avoid tax fraud on the company (Law and Mills, 2017).

Audit Quality and Earnings quality. (Asthana, 2017) found that audit quality negatively affected by Public Accounting Firms office diversifications, possibly appeared because it 
puts pressure on existing resources at public accounting firms. (Bell et al., 2015) found that first-year audits show lower audit quality testing, quality increases thereafter and then decreases as tenure proceeds longer. An audit quality decrease in the long audit tenure on private clients, while in companies registered with the SEC audit quality reaches a maximum with a longer tenure. (Broberg et al., 2017) find that audit time pressure decreases the quality of audits conducted by auditors in Sweden. Gender characteristics, assigned duties or positions, work experience and amount of clients handled and the size of local public accounting firms also contributes to the quality of an audit. (Cahan and Sun, 2015) found that audit cost positively affected by work experience but the same doesn't happen to the quality of audit (absolute accrual discretionary). (Chen et al., 2017) found that partners who have work experience in international audit provide higher audit quality. Seen from low accruals, less below the line items, low aggressiveness, CEOs who have international experience tend to be more conservative.

(Chi et al., 2016) found that pre-client audit experience and client-specific experience improve audit quality. The quality of the audit is positively and closely related to partner's audit experience at the initial engagement, not when the partner has audited for at least 5 years. (Habbash and Alghamdi, 2017) find that audit opinion is an indication of earnings management practices. The auditor has no power to regulate the opportunist activities of management. (Houqe et al., 2017) found that audit quality decreases earnings management, also lowering the cost of capital in a group of companies compared to a stand-alone company. (Qi et al., 2017) found that social relationship reduces audit quality, as evidenced in when a client has social relationship with auditors have lower earnings quality, tend to accept net opinions and report lower earnings compared to clients who has no social ties. Furthermore, this phenomenon is stronger in work relationship compared to education relationship. Social relationship affects audit quality which moderated by the auditor's characteristics (Gender, assigned duties or positions, education and work experience).

(Kang et al., 2016) found that higher compensation at public accounting firms improved audit quality. In addition, researchers found higher audit quality in public accounting firms with a higher educational cost, when audit quality was measured using the level of conservatism in the client's financial statements. (Francis and $\mathrm{Yu}, 2009$ ) found that larger Big 4 public accounting firms offices were able to give better audit quality. In particular, this public accounting firms have better chance to publish going-concern reports and its clients are shown to have lower earning management behavior.

(Astami et al., 2017) found that managers of a company with abundance of cashflow, will make investment that don't always benefits the shareholder and make a report stating the company had increased earnings through their accounting works. The findings also describe that audit quality mitigates earnings management and moderates the impact of having cashflow abundance towards the company growth and earnings management

Hypothesis. Management has full control in decision making with certain limitations mandated by shareholders. Shareholders cannot supervise management in managing the company at any time, this opens the opportunity for management to manage the company not in accordance with the expectations of shareholders, even taking decisions that can harm the interests of shareholders. One of the important outputs made by management is the financial statements, where it functions as management accountability tool to shareholders in annual shareholders meeting. Preparing the financial statements is the responsibility of 
management, they also can intervene or manipulate the financial statements reported to shareholders. In general, management's accountability is contained in a management contract / KPI (Key Performance Indicators) determined by the shareholders. The most important thing to measure KPI in general is the company's net profit or earnings.

When related to agency theory, directors and commissioners who have a military background can be one mechanism that can increase stakeholder confidence and can maintain the quality of audits that will be obtained by the company. The relationship between military background and audit quality has not been supported by previous research. However, logically thinking and linked to agency theory, the presence of CEOs with a military background fixes agency problems between companies and their shareholders, especially in settings where the problem is potentially acute. Consideration of the possibility of such a relationship was obtained from research conducted by (Benmelech and Frydman, 2015) which concluded that CEOs with a military background tend to be conservative / careful in making decisions and minimal fraud occurs. (Law and Mills, 2017) revealed in their research that managers with a military background have a tendency to avoid tax fraud, so that tax payments are greater than other companies. The initial hypothesis of this research is that military background will improve audit quality due to the tendency of CEO / top management commitment to maintain the quality of good corporate governance. Researchers arrange the hypothesis to be tested as follows:

\section{H1: Military background has positive effect towards audit quality.}

Previous studies outcome do not show a direct relationship between military background and earnings quality, but the results of previous studies indicate that the CEO or manager is able to provide a significant influence on company performance. Companies that have a CEO with a military background have better performance and minimal fraud occurs in the company, thus the profits reported by the company can be believed to achieve a high level of earnings quality. Based on this, the following hypotheses can be arranged:

\section{H2: Military background has a positive effect towards earnings quality.}

Companies which have familiar relationship with governmental institutions or figures could be categorized as companies with political connections. They are also risk takers, so the possibility of failure is very large (Wahab et al., 2011). This company is called a risk taker company because it often uses its influence to get easier access to obtain soft loans (Wahab, 2011). Soft loans are used by companies to overcome the crisis that is happening because companies that have political connections are likely to experience greater failure (Gul, 2006). In addition, audits are at higher risk because there is a greater likelihood of reporting errors and overstatement in earnings to avoid debt obligations (Gul, 2006). This requires an auditor who can detect this. This is related to the quality of the auditor. Public accounting firms that have big names (Big 4) will provides higher audit quality compared to public accounting firms that do not have big names. The hypothesis that researchers compiled as follows:

H3: Political connections has a negative effect towards audit quality. 
Research that examines political connections and earnings quality was conducted by (Harymawan and Nowland, 2016), the results of the study concluded that earnings quality is influenced by political connections owned by companies. The influence of this political connection is mediated by the conditions of political stability and governance that occur. (Qi et al., 2017) examined the relationship between social ties and audit quality, and concluded that companies that have social connections with auditors on duty have low audit quality and tend to get clean opinions and report lower earnings compared to clients who has no social ties. From some of these studies in general it can be concluded that companies that have connections with influential external parties / power will have a significant influence that affects the quality of corporate earnings with the following hypotheses:

\section{H4: Political connections negatively affect earnings quality.}

A strong relation between audit quality and earnings quality has been highlighted by several studies. According to $(\mathrm{Hu}, 2015)$ stated in the conceptual framework suggested in his research shows that one proxy that can be used to measure audit quality is to use earnings quality itself. In addition, (Houqe et al., 2017) concluded in their research that audit quality decreases earnings management by companies. Some of these studies shows evidence that audit audit quality can enhance the quality of earnings which presented within the audited financial statements. According to this description, the hypothesis is structured as follows:

\section{H5: Audit quality has a positive effect towards earnings quality.}

Appointment of company management by shareholders actually gives flexibility to shareholders to choose a management structure that can meet their aspirations, but in accordance with Agency Theory, that management appointed to represent shareholders in managing the company also has its own interests. Thus, the information difference is happened between the management and the shareholders. As the management have the power to make the company's financial statements, this brings a great opportunity for the management to makes profit adjustments on the reported financial statements. This condition shows a significant influence of management's role on the reported earnings quality of the company.

CEOs with a military background have a tendency to take more conservative or cautious decisions, so companies tend to have a small chance to commit fraud (high internal control) and obey the law, the company also has better performance compared to companies that do not have a CEO military background. CEOs with a military background will consider the selection of auditor quality, this will affect how the company reports their earning quality. The auditor in conducting an audit based on audit standards will find and make corrections to the mistakes made by management in preparing financial statements. In this way, the quality of earnings which will be reported by the management will be further enhanced by the high audit quality.

Research managed by (Wahab, 2011) found that audit fees are heavily influenced by the company's political connection. In another research conducted by (Gul, 2006) also states that audit fees are significantly and positively affected by political connections. Companies will pay higher audit fees, usually, when using a public accountant firm that has a big name (Big-4) which will provides the company with higher audit quality than a public accounting 
firm that does not have a big name (DeAngelo, 1981). According to this explanation, the hypothesis is structured as follows:

H6: Military background has a positive effect towards earnings quality through audit quality.

Using their connections within political or governmental sphere, risk taker companies have better access to soft loans (Wahab, 2011). Companies which have familiar relationship with governmental institutions or figures could be categorized as companies with political connections. Companies that have political connections are risk takers, so the possibility of failure is very large (Wahab et al., 2011). The auditor in conducting an audit based on audit standards will find and make corrections to the mistakes made by management in preparing financial statements. High audit quality will further improve the quality of earnings reported by management. According to this description, the hypothesis is structured as follows:

H7: Political connections negatively affect earnings quality through audit quality.

\section{METHODOLOGY}

Sample and data sources. The sample used on this research consist of mining companies which listed on the Indonesia Stock Exchange with their financial statements taken from the period between 2017-2018. Initial research data obtained a total of 78 sample observations, then we selected sample criteria, namely we excluded companies that did not have financial reports on the Indonesia Stock Exchange and companies that suffered losses. The final results obtained as many as 50 samples.

Measurement of military background. One previous research conducted by (Benmelech and Frydman, 2015) which uses military background variables, which focus on corporate CEOs. Whereas in this research, we define this background to be one or a part of the Board of Commissioners (BOC) and Board of Directors (BOD) who have military background (having positions in the military or ex-military in Indonesia). This variable is measured by looking at whether a company has management with a military background given a dummy score $=1$, and 0 otherwise.

\section{Military Background $=1$ if exist and 0 if not exist}

Measurement of political connections. Political connections can be seen from the connections or relationship which owned by the Board of Commissioners (BOC) and Board of Directors (BOD) of the company, both connections to government and connections to political parties. Political connections is measured using the dummy variable $=1$ if it has political connection and 0 otherwise.

\section{Political Connection $=1$ if exist and 0 if not exist}

Audit quality measurement. The standard of measurement of audit quality is calculated using the size of Public Accounting Firm who conducts the audit, which is Big-4 and nonBig-4. (Astami et al., 2017) research revealed that several previous studies explain a clear distinguished measurement between Big-4 and non-Big-4 auditors, for example (Persakis 
and Iatridis, 2016) research concluded that the Big-4 auditors results in reduced earnings manipulation. (Casey et al., 2015) found that companies who use auditors with good reputations can reduce the earnings management done by clients. As stated by (Hu, 2015), one measurement of audit quality is the size of the Public Accounting Firm which conducting the audit. The audit quality variable uses the Public Accounting Firm size measured by using the dummy variable size $=1$ for the group of companies audited by the Big-4 and is 0 if otherwise.

\section{Audit Quality $=1$ if audited by Big-4 and 0 if audited by non-Big-4}

Measurement of earnings quality. A model modification made by (Dechow et al., 1995), which designed to reduce the allegation of the Jones model in error measuring discretionary accruals, when discretionary is made on income. In this modified model, non-discretionary accruals are estimates of the event period, i.e during the period of the expected earnings quality. This measure is also usually used by researchers in measuring earnings management. Higher value of earnings management indicates that the company has a lower quality of financial statement presentation (lower earnings quality). formula:

Discretionary Accruals calculated as follows. First, calculate total accruals using

$$
T A C_{i t}=N I_{i t}-C F O_{i t}
$$

Second, Total accruals then estimated with regression using SPSS calculated as:

$$
T A C_{i t} / A_{i t-1}=\beta_{1}\left(1 / A_{i t-1}\right)+\beta_{2}\left(\Delta R E V_{i t} / A_{i t-1}\right)+\beta_{3}\left(P P E_{i t} / A_{i t-1}\right)+e .
$$

Third, Calculate non discretionary accruals (NDA) using $\beta_{1}, \beta_{2}$ and $\beta_{3}$ from above calculation using formula

$N D A_{i t}=\beta_{1}\left(1 / A_{i t-1}\right)+\beta_{2}\left(\Delta R E V_{i t} / A_{i t-1}-\Delta R E C_{i t} / A_{i t-1}\right)+\beta_{3}\left(P P E_{i t} / A_{i t-1}\right)+e$

Finally, discretionary accruals is the residual (total accruals minus non-discretionary accruals).

Where:

$T A C_{i t}=$ total accruals for firm $\mathrm{i}$ in time period $\mathrm{t}$

$N I_{i t} \quad=$ net income for firm $\mathrm{i}$ in time period $\mathrm{t}$

$\mathrm{CFO}_{i t} \quad=$ cash flow from operation for firm $\mathrm{i}$ in time period $\mathrm{t}$

$\mathrm{A}_{\text {it }-1}=$ total asset for firm $\mathrm{i}$ in year $\mathrm{t}-1$

$\mathrm{NDA}_{\text {it }}=$ non-discretionary accruals for firm $\mathrm{i}$ in time period $\mathrm{t}$

$\mathrm{PPE}_{\mathrm{it}} \quad=$ property, plant and equipment for firm $\mathrm{I}$ in time period $\mathrm{t}$

$\Delta \mathrm{REV}_{\mathrm{it}} \quad=$ change net sales for firm $\mathrm{i}$ between years $\mathrm{t}-1$

$\Delta \mathrm{REC}_{\mathrm{it}} \quad=$ change in receivables for firm $\mathrm{i}$ between years $\mathrm{t}-1$

Control Variables. This research using three control variables which includes return on assets (ROA), firm leverage ratio (LEVERAGE) and firm size (SIZE).

Data analysis begins with descriptive statistics from the samples used in this study, to see the composition and distribution of the political connection, military background, audit 
quality and earning quality. Furthermore, hypothesis testing is performed using regression in the SmartPLS application with the following model:

$$
\begin{aligned}
& A U D I T O R=\alpha+\beta 1 M I L I T E R-\beta 2 P O L C O N+\beta 3 S I Z E+\beta 4 L E V E R A G E+\beta 5 R O A+\varepsilon \\
& \text { EARNING QUALITY }=\alpha+\beta 6 \text { MILITER }-\beta 7 P O L C O N+\beta 8 A U D I T O R+\beta 9 S I Z E+ \\
& \beta 10 L E V E R A G E+\beta 11 R O A+\varepsilon
\end{aligned}
$$

\section{THE RESULTS OF STATISTICAL TESTS}

Descriptive statistics. As shown on Table 1 below, is the descriptive statistics of the sample used in this research. From the sample used, it was found that from the total sample, 32\% of the sample companies had management with a military background, $16 \%$ of the companies had political connections and $48 \%$ of the companies were audited by Big- 4 . The

\begin{tabular}{|c|c|c|c|c|c|}
\hline & $\mathbf{N}$ & Minimum & Maximum & Mean & Std. Deviation \\
\hline MILITARY & 50 & 0 & 1 & 0,320 & 0,471 \\
\hline POLCON & 50 & 0 & 1 & 0,160 & 0,370 \\
\hline AUDITOR & 50 & 0 & 1 & 0,480 & 0,505 \\
\hline $\begin{array}{l}\text { EARNING } \\
\text { QUALITY }\end{array}$ & 50 & $-0,2601$ & 0,1805 & $-0,0129$ & 0,08782 \\
\hline SIZE & 50 & 27,2747 & 32,2597 & 29,2794 & 1,2921 \\
\hline LEVERAGE & 50 & 0,1606 & 13,1520 & 1,3678 & 2,1062 \\
\hline ROA & 50 & $-0,0117$ & 0,4308 & 0,0985 & 0,1064 \\
\hline $\begin{array}{l}\text { Valid N } \\
\text { (listwise) }\end{array}$ & 50 & & & & \\
\hline
\end{tabular}
average return on assets is $9.8 \%$ and the average leverage of the company is $136 \%$.

Table 1. Descriptive statistics

Main analysis. In this section, we conduct empirical testing to discover military background and political connections effect on audit quality and earnings quality. Testing the model using the PLS (Partial Least Square) model using 50 research samples. 
Figure 1. Testing the model using PLS

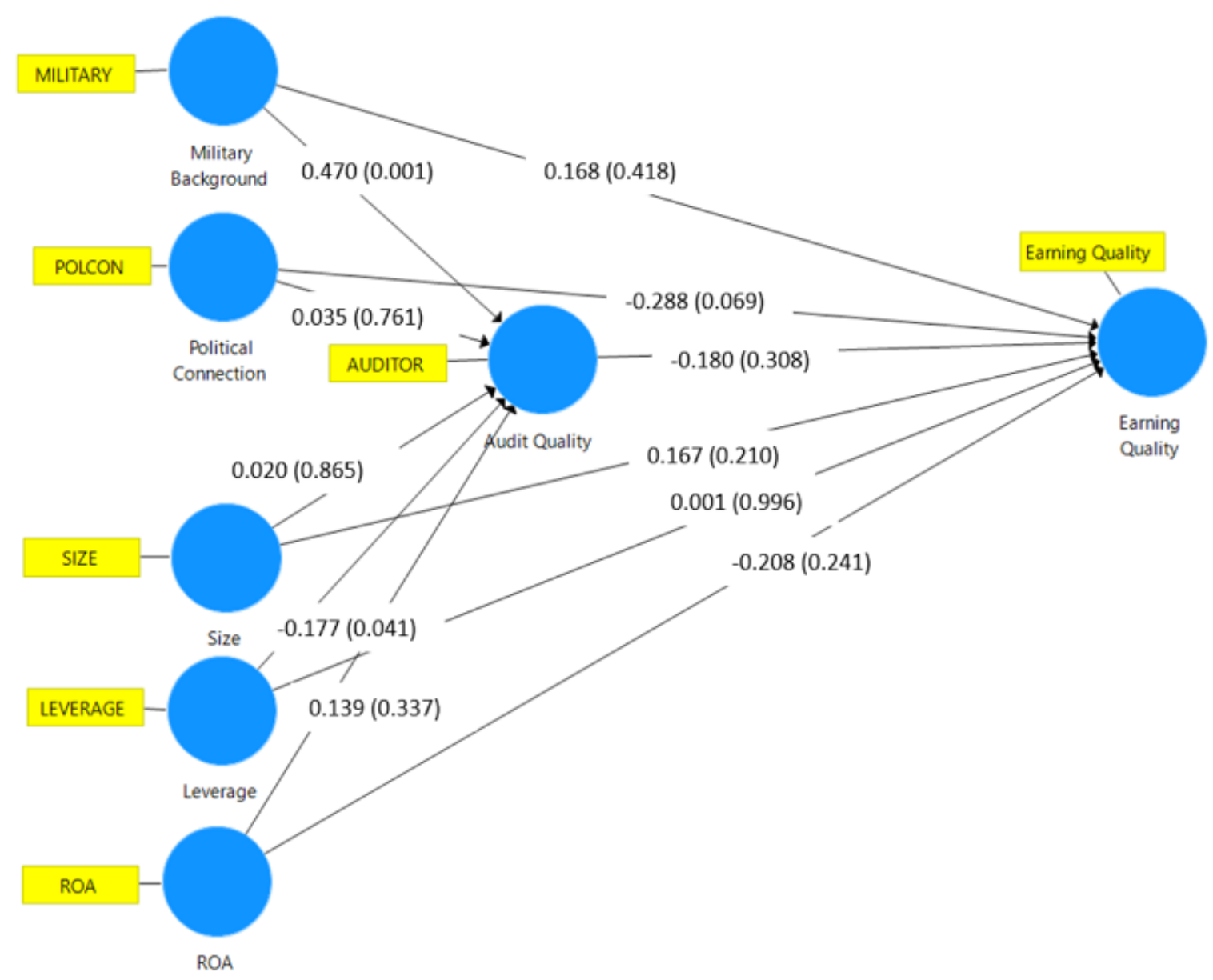

Source: Output Model SmartPLS

Figure 1 shows the results of testing a research model using PLS. Based on this model it can be concluded that judging from direct effects, only military background has an effect towards audit quality with a significance value of 0.001 and t-values of 3.261 (greater than the t-value of 1.96) and has a positive coefficient of 0.470 . Furthermore, political connection has an effect on earnings quality and has a negative coefficient of -0.288 with a significance value of 0.069 . 
Table 2. Summary of hypotheses testing results

\begin{tabular}{|c|c|c|c|c|}
\hline Direct Effects & Coefficients & T-Values & P-Values & Conclusion \\
\hline Military -> Audit Quality & 0,470 & 3,261 & $0,001 *$ & Hypothesis accepted \\
\hline Military -> Earning Quality & 0,168 & 0,811 & 0,418 & Hypothesis rejected \\
\hline Polcon -> Audit Quality & 0,035 & 0,305 & 0,761 & Hypothesis rejected \\
\hline Polcon -> Earning Quality & $-0,288$ & 1,819 & $0,069 \div *$ & Hypothesis accepted \\
\hline Kualitas Audit -> Earning Quality & $-0,180$ & 1,021 & 0,308 & Hypothesis rejected \\
\hline Leverage -> Audit Quality & $-0,177$ & 2,046 & 0,041 & \\
\hline Leverage -> Earning Quality & 0,001 & 0,006 & 0,996 & \\
\hline ROA -> Audit Quality & 0,139 & 0,961 & 0,337 & \\
\hline ROA -> Earning Quality & $-0,208$ & 1,173 & 0,241 & \\
\hline Size -> Audit Quality & 0,020 & 0,170 & 0,865 & \\
\hline Size -> Earning Quality & 0,167 & 1,254 & 0,210 & \\
\hline Indirect Effects & Coefficients & T-Values & P-Values & Conclusion \\
\hline Military - Audit Quality - Earning Quality & $-0,084$ & 0,850 & 0,396 & Hypothesis rejected \\
\hline Polcon - Audit Quality - Earning Quality & $-0,006$ & 0,194 & 0,846 & Hypothesis rejected \\
\hline Leverage - Audit Quality - Earning Quality & 0,032 & 0,831 & 0,831 & \\
\hline ROA - Audit Quality - Earning Quality & $-0,025$ & 0,489 & 0,625 & \\
\hline Size - Audit Quality - Earning Quality & $-0,004$ & 0,119 & 0,906 & \\
\hline R Square and $R-S q u a r e$ Adjusted & R Square & R-Square Adjusted & & \\
\hline Audit Quality & 0,349 & 0,275 & & \\
\hline Earning Quality & 0,173 & 0,057 & & \\
\hline
\end{tabular}

Source: (Summary from SmartPLS, 2020)

Table 2 shows that the hypotheses accepted are $\mathrm{H} 1$ and $\mathrm{H} 4$, where $\mathrm{H} 1$ is a military background which has a positive effect towards the earnings quality of mining sector companies with a significance value of 0.001 (with a significance level of 5\%) and a coefficient of +0.470 . Whereas for $\mathrm{H} 4$, political connections have a negative effect with a significance value of 0.069 (with a significance level of 10\%) and a negative coefficient of -0.288 .

Whereas $\mathrm{H} 2, \mathrm{H} 3, \mathrm{H} 5, \mathrm{H} 6$ and $\mathrm{H} 7$ were not proven in this research. This is because the significance value is greater than $10 \%$. While for the R-Square model 1 value is 0.349 or $34.9 \%$ audit quality variable is influenced by military background, political connections, company size, leverage and profitability while the other $65.1 \%$ is influenced by other nonfundamental factors not examined in this research. For the value of R-Square model 2 is 0.173 or $17.3 \%$ earnings quality variable is influenced by military background, political connections, audit quality, company size, leverage and profitability while the other $82.7 \%$ is influenced by other non-fundamental factors not examined in this research.

Effects of Military Background on Audit Quality. This research results that military background influences audit quality. Agency theory says that Directors and Commissioners who have a military background can be a mechanism that can increase stakeholder confidence and can maintain the quality of audits that will be obtained by the company. The 
presence of CEOs with a military background corrects agency problems between companies and their shareholders, especially in condition where the problem is potentially acute. This supports the research of (Benmelech and Frydman, 2015) which concluded that CEOs with a military background tend to be conservative or careful in making decisions and minimal fraud occurs.

The military background has close relations in the mining sector, although Law no. 34 of 2004 concerning the national army which defines that professional soldiers do not participate in politics, do not engage in business, and are only assigned with maintaining national security. However, the elimination of military dual function has so far been deemed to be not optimal or tends to fail. Although the dual function has been legally "revoked", the military is still interfering in civil matters. Until 2018, the military had more than 30 memorandums of understanding with ministries and other state institutions that allowed them to deal with the civilian sphere (Tempo, 8 February 2018). Military officials occupy strategic positions in plantation, mining, banking, trading and so on. However, companies run by the military are at risk of causing mismanagement and corruption. Soldiers who occupy positions in these companies can illegally channel funds and company revenues into the military rather than contribute to the state. To minimize this risk, Directors and Commissioners who have a military background tend to prioritize audit quality by choosing and being consistent with Big-4 auditors. It can decrease the information asymmetry of corruption, collusion and nepotism in the mining sector. Audit quality is a very important part in presenting reports on audit results consumed by the public or government, so it is expected that audit quality will show good corporate government and good financial management.

Effects of Military Background towards Earnings Quality. This research results shows that earnings quality of a company is not affected by CEOs/Management with Military background. The finding does not support agency theory, that CEOs with a military background have a tendency to take more conservative or cautious decisions, so companies tend to have a small chance of committing fraud (high internal control) revealed by (Benmelech and Frydman, 2015). This is also not in accordance with the research of (Law and Mills, 2017) which explains that avoiding tax fraud is a habit of managers with military background, so that tax payments are greater than other companies.

This research shows that it is not only management with a military background that determines the quality of earnings, the mining sector in general has shown good earnings quality that can be contributed to the country. The mining sector is one sector that contributes high gross domestic product to the country.

Effects of Political Connections towards Audit Quality. This research found that political connections had no effect towards audit quality. Companies in the mining sector have the least political connections to be connected by the government or political parties. The mining sector is more likely to be associated with the military (Wahab, 2011).

Executives and directors who have political connections are considered to have power because they can utilize their links with politicians (Khan et al., 2016). Political interests could alter information from companies with political connections which leads to lowered quality on provided information (Hope et al., 2017). Political interests have an impact on audit failure, chance of a company bailout and the bias arising from media coverage, thereby 
affecting the auditor's judgment and independence. However, in the mining sector it is evident that political connections have no effect towards audit quality, because the sample of companies has little political connection and is strengthened by an audit engagement with a big-name public accounting firm (Big 4) which provides higher audit quality than nonBig-4 public accounting firms.

Effects of Political Connections towards Earnings Quality. This research shows that political connections negatively affect earnings quality with a significance of 0.069 (at a significance level of 10\%). This supports the research of (Harymawan and Nowland, 2016), the results of the research concluded that earnings quality is influenced by political connections owned by companies. Companies that have political connections with outsiders who influence / have power will have significant influence towards the quality of corporate earnings, this is in accordance with agency theory where the fairness of earnings presentation is a very important measure for company performance and improvement in principal welfare.

Effect of Audit Quality towards Earnings Quality. This research shows that audit quality had no effect towards earnings quality. This does not support $(\mathrm{Hu}, 2015)$ research which states that one proxy that can be used to measure audit quality is to use earnings quality itself.

This research is designed to measure audit quality using public accounting firm measurement. Thus, it is estimated that, in terms of excellence of conducting audits, large public accounting firms perform much better than small public accounting firms so they produce higher audit quality. In general, either directly or indirectly, audit quality research in Indonesia is still very limited in validity, namely using public accounting firm size affiliated with Big-4 (Sanjaya, 2008), or the public accounting firm industry specialization (Herusetya, 2009). (Becker et al., 1998) states that there is a relationship between audit quality and earnings quality. In addition, larger public accounting firms are, in most cases, considered to provides high audit quality and have a high reputation in the business environment. The size of the public accounting firms in this research is the size of the public accounting firms that is divided into two groups, namely public accounting firms affiliated with Big-4 and public accounting firms that are not affiliated with Big-4. This means that even good audit quality from the Big-4 auditor class can not control the earnings quality of mining sector companies.

Effects of Military Background towards Earnings Quality through Audit Quality. This research did not find any relationship between audit quality mediation on the relation between military background and earnings quality. The presence of management with a military background corrects agency problems between companies and their shareholders, especially in settings where the problem is potentially acute. This supports the research of (Benmelech and Frydman, 2015) which concluded that CEOs with a military background tend to be conservative / careful in making decisions and minimal fraud occurs.

This research also shows that earnings quality is not affected by managers' military backgrounds. The result does not support agency theory which explains CEOs with a military background have a tendency to take more conservative or cautious decisions, so companies tend to have a small chance of committing fraud (high internal control) revealed 
by (Benmelech and Frydman, 2015). This research shows that it is not only the military background that determines the quality of earnings. The mining sector is one sector that contributes high gross domestic product to the country. It can be concluded, that the military background has only a direct effect on audit quality so that investor confidence in corruption, collusion and nepotism actions can be minimized with the presence of auditors from the Big-4. This research found that audit quality can not mediate the relationship of military background to earnings quality, because the mechanism of earnings quality in the mining sector is not influenced by military background and audit quality, but is influenced by the financial performance of each mining company itself.

Effects of Political Connections towards Earnings Quality through Audit Quality. This research does not find any mediating relationship between audit quality on the relationship of political connections and earnings quality. This research found that political connections had no effect on audit quality. The mining sector is a company that has the least political connections to be connected by the government or political parties. The mining sector is more likely to be associated with the military (Wahab, 2011).

However, this research results that political connections negatively affect earnings quality with a significance of 0.069 (at a significance level of 10\%). This supports the research of (Harymawan and Nowland, 2016), the results of the research concluded that earnings quality is influenced by political connections owned by companies. However, political connections directly affect the quality of earnings, and have nothing to do with audit quality that will produce quality earnings. In terms of financial performance, the mining sector is the most powerful sector among other manufacturing sectors in contributing to the GRDP in Indonesia. For this reason, this sector is still a sector that is always monitored by the government as the biggest contributor and supporter of the economy in Indonesia.

\section{CONCLUSIONS}

This research shows that military background has a significant positive effect on audit quality and political connections does not have a significant effect on audit quality. In contrast to its effect on audit quality, this research found that the military background did not have a significant effect on earnings quality and political connections had a significant negative effect on earnings quality.

The initial hypothesis of the research was that the researcher wanted to find empirical evidence that the effect of mediating audit quality on the influence of military background and political connections on earnings quality was not proven. This research contributes to company management in the research sample, to better understand the effect of military background dan political connection on audit quality and earnings quality.

For further research, can use other independent variables in examining the variables of corporate earnings quality in Indonesia, such as government share ownership, other corporate governance mechanisms that can be used (independent commissioners and audit committees), and can use other audit quality measurements such as audit restatement or audit switch. 


\section{REFERENCES}

Adams, M. B. (1994). Agency Theory and the Internal Audit. Managerial Auditing Journal, 9(8), 8-12. doi:doi:10.1108/02686909410071133.

Astami, E. W., Rusmin, R., Hartadi, B., and Evans, J. (2017). The role of audit quality and culture influence on earnings management in companies with excessive free cash flow: Evidence from the Asia-Pacific region. International Journal of Accounting and Information Management, 25(1), 21-42. doi:10.1108/IJAIM-05-2016-0059.

Asthana, S. (2017). Diversification by the audit offices in the US and its impact on audit quality. Review of Quantitative Finance and Accounting, 48(4), 1003-1030. doi:10.1007/s11156-016-0576-y.

Becker, C. L., DeFond, M. L., Jiambalvo, J., and Subramanyam, K. (1998). The effect of audit quality on earnings management. Contemporary accounting research, 15(1), 124.

Bell, T. B., Causholli, M., and Knechel, W. R. (2015). Audit Firm Tenure, Non-Audit Services, and Internal Assessments of Audit Quality. Journal of accounting research, 53(3), 461-509. doi:10.1111/1475-679X.12078.

Benmelech, E., and Frydman, C. (2015). Military CEOs. Journal of Financial Economics, 117(1), 43-59. doi:https://doi.org/10.1016/j.jfineco.2014.04.009.

Broberg, P., Tagesson, T., Argento, D., Gyllengahm, N., and Mårtensson, O. (2017). Explaining the influence of time budget pressure on audit quality in Sweden. Journal of Management and Governance, 21(2), 331-350. doi:10.1007/s10997-016-9346-4.

Cahan, S. F., and Sun, J. (2015). The Effect of Audit Experience on Audit Fees and Audit Quality. Journal of Accounting, Auditing and Finance, 30(1), 78-100. doi:10.1177/0148558X14544503.

Campa, D. (2013). "Big 4 fee premium" and audit quality: latest evidence from UK listed companies. Managerial Auditing Journal, 28(8), 680-707.

Casey, R. J., Kaplan, S. E., and Pinello, A. S. (2015). Do auditors constrain benchmark beating behavior to a greater extent in the fourth versus interim quarters? Advances in accounting, 31(1), 1-10.

Chen, X., Dai, Y., Kong, D., and Tan, W. (2017). Effect of international working experience of individual auditors on audit quality: Evidence from China. Journal of Business Finance and Accounting, 44(7-8), 1073-1108. doi:10.1111/jbfa.12257.

Chi, W., Myers, L. A., Omer, T. C., and Xie, H. (2016). The effects of audit partner preclient and client-specific experience on audit quality and on perceptions of audit quality. Review of Accounting Studies, 22(1), 361-391. doi:10.1007/s11142-0169376-9.

DeAngelo, L. E. (1981). Auditor size and audit quality. Journal of Accounting and Economics, 3(3), 183-199.

Dechow, P. M., Sloan, R. G., and Sweeney, A. P. (1995). Detecting earnings management. Accounting Review, 193-225.

Fan, J. P. H., Wong, T. J., and Zhang, T. (2007). Politically connected CEOs, corporate governance, and Post-IPO performance of China's newly partially privatized firms. Journal of Financial Economics, 84(2), 330-357. doi:https://doi.org/10.1016/j.jfineco.2006.03.008. 
Francis, J. R., and Yu, M. D. (2009). Big 4 office size and audit quality. The Accounting Review, 84(5), 1521-1552.

Gul, F. A. (2006). Auditors' response to political connections and cronyism in Malaysia. Journal of accounting research, 44(5), 931-963.

Habbash, M., and Alghamdi, S. (2017). Audit quality and earnings management in less developed economies: the case of Saudi Arabia. Journal of Management and Governance, 21(2), 351-373. doi:10.1007/s10997-016-9347-3.

Harymawan, I., and Nowland, J. (2016). Political connections and earnings quality: How do connected firms respond to changes in political stability and government effectiveness? International Journal of Accounting \& Information Management, 24(4), 339-356.

Herusetya, A. (2014). Pengaruh ukuran auditor dan spesialisasi auditor terhadap kualitas laba. Jurnal Akuntansi dan Keuangan Indonesia, 6(1), 46-70.

Hope, O.-K., Yue, H., and Zhong, Q. (2017). Do politically connected directors affect accounting quality? Evidence from China's anti-corruption campaign (Rule 18).

Houqe, M. N., Ahmed, K., and van Zijl, T. (2017). Audit Quality, Earnings Management, and Cost of Equity Capital: Evidence from India. International Journal of Auditing, 21(2), 177-189. doi:10.1111/ijau.12087.

$\mathrm{Hu}, \mathrm{D}$. (2015). Audit quality and measurement: towards a comprehensive understanding. Academy of Accounting and Financial Studies Journal, 19(1), 209.

Kang, M., Lee, H.-Y., Son, M., and Stein, M. (2016). The association between human resource investment by audit firms and their audit quality. Asia-Pacific Journal of Accounting \& Economics, 24(3-4), 249-271. doi:10.1080/16081625.2016.1214605.

Khan, A., Mihret, D. G., and Muttakin, M. B. (2016). Corporate political connections, agency costs and audit quality. International Journal of Accounting \& Information Management.

Law, K. K., and Mills, L. F. (2017). Military experience and corporate tax avoidance. Review of Accounting Studies, 22(1), 141-184. doi:10.1007/s11142-016-9373-Z.

Persakis, A., and Iatridis, G. E. (2016). Audit quality, investor protection and earnings management during the financial crisis of 2008: An international perspective. Journal of International Financial Markets, Institutions and Money, 41(Supplement C), 73101. doi:https://doi.org/10.1016/j.intfin.2015.12.006.

Qi, B., Yang, R., and Tian, G. (2017). Do social ties between individual auditors and client CEOs/CFOs matter to audit quality?*. Asia-Pacific Journal of Accounting and Economics, 24(3-4), 440-463. doi:10.1080/16081625.2015.1135067.

Sanjaya, I. P. S. (2008). Auditor Eksternal, Komite Audit, dan Manajemen Laba Sanjaya. The Indonesian Journal of Accounting Research, 11(1).

Wahab, E. A. A., Zain, M. M., and James, K. (2011). Political connections, corporate governance and audit fees in Malaysia. Managerial Auditing Journal. 